Utah State University

DigitalCommons@USU

T.W. "Doc" Daniel Experimental Forest

Quinney Natural Resources Research Library,

S.J. and Jessie E.

1980

\title{
Infection of Engelmann-Spruce Seed by Geniculodendron pyriforme in Western North America
}

M W. Wicklow-Howard

Follow this and additional works at: https://digitalcommons.usu.edu/docdan

Part of the Plant Sciences Commons

\section{Recommended Citation}

Wicklow-Howard, M.W. and J. Skujins (1980). Infection of Engelmann spruce seeds by Geniculodendron pyriforme in Western North America. Mycologia, 72(2): 406-410.

This Article is brought to you for free and open access by the Quinney Natural Resources Research Library, S.J. and Jessie E. at DigitalCommons@USU. It has been accepted for inclusion in T.W. "Doc" Daniel Experimental Forest by an authorized administrator of DigitalCommons@USU.

For more information, please contact digitalcommons@usu.edu.

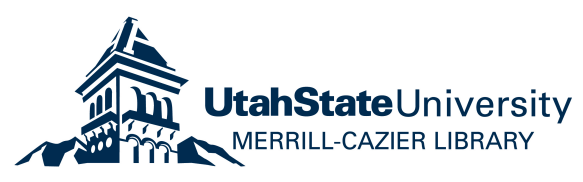


among isolates obtained from the same soil sample. Our data indicate that different genotypes were isolated including isolates from soil samples where mating types were predominantly or entirely $(+)$ or $(-)$.

Only $12 \%$ of the soil samples converted completely to the yeast phase in vitro, but this compares favorably with the $6 \%$ total conversion rate obtained by Kwon-Chung et al. (1974) with their soil isolates. In our study there was not a good correlation between complete convertability and mating type, as can be seen in TABLE I. Of the 42 isolates $(12 \%)$ which did convert well, 22 were $(+)$ type, 20 were $(-)$ type. It is also interesting to note that $52 \%$ of the isolates from gull nests converted completely to the yeast phase, well above the percentage obtained with isolates from the blackbird sites.

We acknowledge with appreciation financial assistance from NIH Grant AI14936 and the University of Kansas General Research allocations \#3676, 3210, and 3398.

\title{
LITERATURE CITED
}

Gaur, P. K., and R. W. Lichtwardt. 1980. Preliminary visual screening of soil samples for the presumptive presence of Histoplasma capsulatum, Mycologia $72: 259-269$.

Kwon-Chung, K. J. 1972a. Sexual stage of Histoplasma capsulatum. Science $175: 326$.

- 1972b. Emmonsiella capsulata: perfect state of Histoplasma capsulatum. Science 177 : 283-285.

- 1973. Studies on Emmonsiella capsulata. I. Heterothallism and development of the ascocarp. Mycologia 65 : 109-121.

, R. J .Weeks, and H. W. Larsh. 1974. Studies on Emmonsiella capsulata (Histoplasma capsulatum). II. Distribution of the two mating types in 13 endemic states of the United States. Amer. J. Epidemiol. 79: 44-49.

McGinnis, M. R., and B. Katz. 1979. Ajellomyces and its synonym Emmonsiella. Mycotaxon 8: 157-164.

\section{INFECTION OF ENGELMANN-SPRUCE SEED \\ BY GENICULODENDRON PYRIFORME IN WESTERN NORTH AMERICA}

\author{
M. C. Wicklow-Howard \\ Department of Biology, Boise State University, Boise, Idaho 83725 \\ AND \\ J. Skujins \\ Department of Biology, Utah State University, Logan, Utah 84322
}

Geniculodendron pyriforme Salt was identified and characterized by Salt (1974) as the fungus responsible for germination failure of Sitka 
spruce [Picea sitchensis (Bong.) Carr.] seed in Canadian and British forest nurseries. It was confirmed that the fungus isolated by Epners (1964) from seed of Pinus resinosa Ait., P. sylvestris L., P. strobus L., and Picea glauca (Moench.) Voss. in Canadian nurseries was the same (Salt, 1974). In addition, Salt (1970) demonstrated that the pathogen can infect seeds of western hemlock [Tsuga heterophylla (Raf.) Sarg.], lodgepole pine (Pinus contorta Dougl. ex Loud.), Japanese larch [Larix leptolepis (Sieb. and Zucc.) Gord.] and Douglas-fir [Pseudotsuga menziesii (Mirb.) Franco].

In the western United States, natural regeneration of certain strands of Englemann spruce (Picea engelmanni Parry ex Engelm.) is hampered by a pathogenic agent limiting seed germination. Geniculodendron pyriforme has been identified by the authors as the pathogenic fungus infecting the embryo and endosperm of overwintering seeds of Engelmann spruce. Geniculodendron pyriforme is known from Ontario, Canada (Epners, 1964), and in western North America from British Columbia, Canada, and Washington, USA (Salt, 1970). The present paper is an account of $G$. pyriforme infection in western Engelmannspruce forests, where it invades not only Engelmann-spruce seed but also seed of the associated conifer species, subalpine fir [Abies lasiocarpa (Hook.) Nutt.].

Engelmann-spruce forest litter containing seed was collected from sites in Utah, Colorado, Arizona, Idaho and Wyoming. Infected seed often can be distinguished from normal viable seed by the fact that the former have varying amounts of blue discoloration of the seed coat and endosperm. However, reliable detection of seed infection and isolation of the pathogen can be accomplished by placing dissected portions of embryo and endosperm from surface-sterilized seed onto $\mathrm{V}$-8-juice agar and incubating at $20 \mathrm{C}$. After $6 \mathrm{da}$ at $20 \mathrm{C}$, the hyaline, aerial mycelium of the fungus can be seen growing from the infected portions. Further growth results in the formation of distinctive white, floccose colonies with conspicuous blue-colored areas. This blue coloration is intensified if other fungi or bacteria are growing in close proximity. Sporulation is evident after 4 wk of growth. The conidiogenous apparatus has a welldefined main axis and distinct dendritic branching. The conidia are produced in sympodial succession and form clusters at the apices of conidiogenous cells. Geniculodendron pyriforme infection could be demonstrated only in seeds sifted from litters collected in the Cache National Forest, Utah and Payette National Forest, Idaho (TABLE I).

In addition, healthy Englemann-spruce seeds, gathered in the fall from cones which had newly dropped, were stratified at $2 \mathrm{C}$ in litters collected from the same sites throughout the intermountain area in an 
TABLE I

Geniculodendron pyriforme IN SEEDS OR LITTER FROM VARIOUS SITES IN THE INTERMOUNTAIN AREA

\begin{tabular}{lcc}
\hline \hline \multicolumn{1}{c}{ Location } & $\begin{array}{c}\text { Infection } \\
\text { in seeds } \\
\text { stratified in } \\
\text { Engelmann- } \\
\text { spruce litter }\end{array}$ \\
\hline squeds & - & + \\
Cedar Break, Utah & - & + \\
Mirror Lake, Utah & - & + \\
Barney Top, Utah & - & + \\
San Francisco Mts., Arizona & - & + \\
Mt. Graham, Arizona & - & + \\
Monarch Pass, Colorado & - & + \\
Buckskin Creek, Colorado & - & + \\
Fraser Expt. Stn., Colorado & + & + \\
Cache National Forest, Utah & + & + \\
Payette National Forest, Idaho & $*$ & + \\
Skalkaho Pass, Idaho & - & - \\
Togwotee Pass, Wyoming & & + \\
\hline
\end{tabular}

* No seed could be found in the litter.

attempt to discover presence of the pathogen in the litter. Following 2 mo of incubation the seeds were retrieved and germinated on water agar. Nongerminating seeds were then surface sterilized with $0.1 \%$ silver nitrate, dissected, and portions placed on V-8 agar to be incubated at 20 and $10 \mathrm{C}$. Engelmann-spruce litter from Utah, Arizona, Colorado and Idaho contained the pathogen (TABLE I). Control seeds placed in sterile Petri dishes at $2 \mathrm{C}$ for several mo remained healthy with high germination rates.

The presence of $G$. pyriforme in materials normally present in Engelmann-spruce litter (needles, cone scales, seed wings, sterile seed) also was investigated. Methods used to isolate or observe the pathogen on these materials included: detergent wash, surface sterilization and epidermal impression. We were unable to isolate or show the presence of $G$. pyriforme in any of these materials. The organism can be found only in seeds which have been in contact with the litter either in the laboratory or in the field.

To demonstrate the percentage of seeds infected as well as the season when most infection occurs, in situ studies were undertaken using viable, noninfected seed taken from newly dropped cones and planted into the $\mathrm{O}_{1}$ and $\mathrm{O}_{2}$ layers of the Englemann-spruce stand in Cache National Forest, Utah. The seeds were planted in fall 1975 and harvested at regular weekly intervals from January through June 1976. 

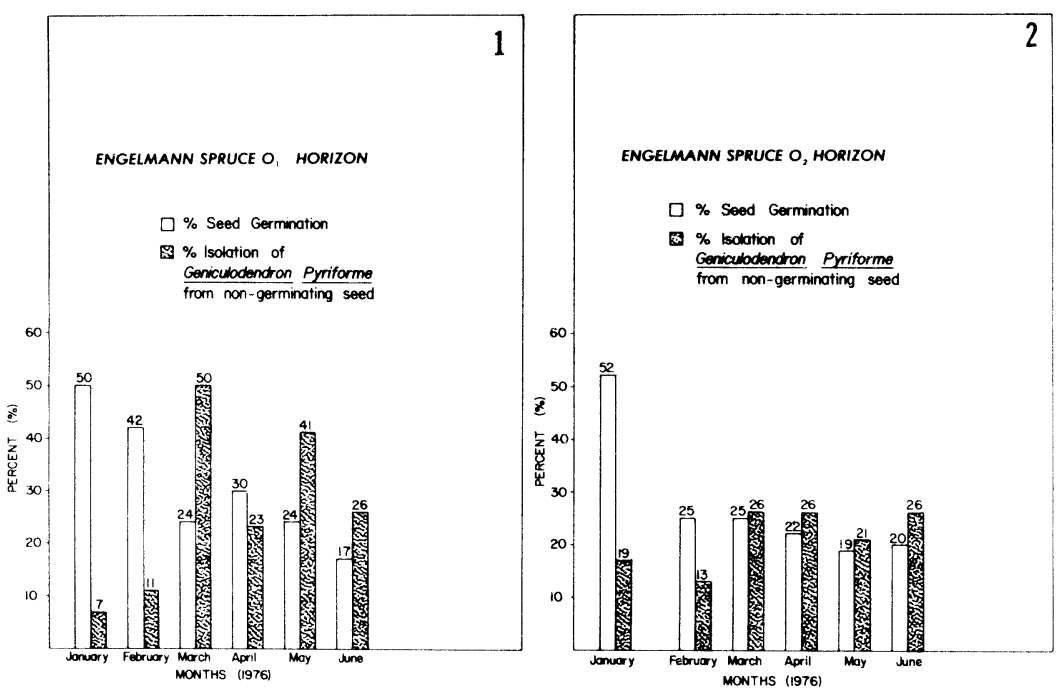

Figs. 1, 2. Percent germination of Engelmann-spruce seed and occurrence of Geniculodendron pyriforme at mo intervals.

There was fair to good germination with a low incidence of $G$. pyriforme infection during the coldest mo of January and February. As temperatures warmed in March, April and May (to about $0 \mathrm{C}$ or above), percent germination decreased while occurrence of $G$. pyriforme increased (FIGs. 1 and 2 ).

TABLE II

GROWTH OF Geniculodendron pyriforme AND OTHER FUNGAL ISOLATES FROM ENGELMANN-SPRUCE LITTERS AFTER 28 DA AT $10 \mathrm{C}$

\begin{tabular}{lc}
\hline \multicolumn{1}{c}{ Test organism } & $\begin{array}{c}\text { Average colony } \\
\text { diam, mm }\end{array}$ \\
\hline Geniculodendron pyriforme & 39 \\
Mycelia sterilia & 32 \\
Chrysosporium sp. & 26 \\
Stephanosporium sp. & 14 \\
Penicillium sp. & 18 \\
Mortierella isabellina Oudemans \& Koning & 31 \\
Cephalosporium sp. & 20 \\
Chaetomium sp. & 42 \\
Trichoderma sp. & 42 \\
Absidia sp. & 85 \\
Aureobasidium pullulans (deBary) Arnaud & 26 \\
Cylindrocarpon sp. & 30 \\
Acremonium sp. & 22 \\
\hline
\end{tabular}


Growth of $G$. pyriforme in vitro is good at $10 \mathrm{C}$, in contrast to the very poor growth of most other fungal isolates from Engelmann-spruce litter. When tested with 12 other fungi for growth at $10 \mathrm{C}, \mathrm{G}$. pyriforme exhibited an average colony diam that was greater than the average diam of nine of the other litter fungi after 28 da (Table II). Similar tests at $22 \mathrm{C}$ indicated that most fungi were able to outgrow G. pyriforme.

In the ecologically competitive situation, G. pyriforme appears to exhibit its maximum pathogenicity in the spring upon snowmelt when temperatures are 2 to $12 \mathrm{C}$. Little is known about its life history or its mode of infection; however, it seems to be present in litter and to infect through contact with seed in that substrate.

\title{
LITERATURE CITED
}

1. Epners, Z. 1964. A new psychrophilic fungus causing germination failure of conifer seeds. Canad. J. Bot. 42: 1589-1604.

2. Salt, G. A. 1970. Conifer seedling pathology. Rep. For. Res. 1970: 174-175.

3. - 1974. Etiology and morphology of Geniculodendron pyriforme gen. et sp. nov., a pathogen of conifer seeds. Trans. Brit. Mycol. Soc. 63 : 339-351.

\section{VEGETATIVE PROPAGATION OF SOME SAPROLEGNIACEAE UNDER SIMULATED-ESTUARINE-CULTURE CONDITIONS ${ }^{1}$}

\author{
David E. PadgetT \\ Department of Biology, The University of North Carolina, \\ Wilmington, North Carolina 28403
}

The vegetative phases of saprolegniaceous fungi are more tolerant of salinity stress than are the asexual and sexual reproductive structures (Te Strake, 1959; Harrison and Jones, 1974). In this connection, Harrison and Jones (1974) have stated that, “. . . the inhibitions imposed by salinity on reproduction ... of these organisms confines them to fresh water or water of extremely low salinity." This statement supports results of field studies such as that of Te Strake (1959), which suggest that water molds do not grow actively in estuarine waters where salinity exceeds about 2.8 parts per thousand (ppt).

${ }^{1}$ Financial support provided by the UNC-Wilmington Marine Sciences Program and National Science Foundation grant DEB 78-10611. 